\title{
PHOTOVOLTAIC CELL ELECTRO-FENTON OXIDATION PROCESS FOR TREATMENT OF ORGANIC CONTENT IN METHYL ORANGE WASTEWATER
}

\author{
AHMED SAMIR NAJE*1, ISRA'A SADI SAMAKA², HAIDER M. ZWAIN² AND MOHAMMED \\ A. AJEEL ${ }^{4}$ \\ ${ }^{1,3}$ College of Water Resources Engineering, AL-Qasim Green University, Babylon, Iraq. ${ }^{2}$ Department of Environmental \\ Engineering, College of Engineering, University of Babylon, Babylon, Iraq ${ }^{4}$ Department of Environment, Faculty of \\ Environment and Energy, Al-Karkh University of Science, Iraq.
}

*Corresponding author: ahmednamesamir@yahoo.com

Submitted final draft: 1 July $2020 \quad$ Accepted: 10 August 2020

http://doi.org/10.46754/jssm.2021.06.005

\begin{abstract}
This paper explores the performance of Photovoltaic cell Electro-Fenton oxidation during the treatment of methyl orange wastewater. The treatment setup comprises a photovoltaic cell, a battery, DC to AC inverter and an electrooxidation reactor. Throughout the Photovoltaic cell Electro-Fenton oxidation experiment, the effect of operating parameters like current, $\mathrm{H}_{2} \mathrm{O}_{2}$, rotation speed and electrolysis time on the total organic carbon and energy consumption were examined. The optimization study was performed by varying the current (0.5-2 mA), hydrogen peroxide (25-100 mg/L), $\mathrm{rpm}(100-$ 200), and the electrolysis time (5-15 min) using response surface methodology (RSM) and Minitab-17. The $\mathrm{pH}$ and the amount of $\mathrm{NaCl}$ in the solution were maintained as $3,0.2 \mathrm{~g}$ respectively. The optimization study shows that $98 \%$ removal efficiency is achievable, consuming $39.4 \mathrm{kWh} / \mathrm{m}^{3}$ energy.
\end{abstract}

Keywords: Dye wastewater, organic content, wastewater treatment, electro-Fenton.

\section{Introduction}

Among the numerous forms of worldwide pollution found nowadays, water contamination is the most prevalent. According to the World Bank, the industrial water effluents account for about $20 \%$ of world water contamination (Haider T. Naeem \& Ali A. Hassan, 2018). Dye wastewater, if not professionally treated, could constitute an ecological issue because of its poisonous nature and potential carcinogenic consequence, which could cause permanent injury to human health and the environment (X. Li et al., 2017; Ali Saleh Jafer et al., 2019). Due to the ecological rules, which demand the reuse and treatment of dye wastewater, many researchers have focused on the removal of organic content in wastewater (Ali A. Hassan et al., 2018). Conventional treatments of dye wastewater have proven to be nonviable because of the emergence of their toxic, nonbiodegradable and intractable effluence. The development of suitable alternative techniques is urgently needed because potable water is a precious commodity in numerous regions of the world (Alvarez-Corena et al., 2016; Ali A. Hassan \& Khalid M. Mousa Al-zobai, 2019;
Fathy et al., 2017 ; Galvão et al., 2006; Hassan $\&$ Haider T. Naeem, 2019). Various conservative methods have been used to eliminate organic matter from wastewater: biological treatment (Q. Li et al., 2005), adsorption (El-Din et al., 2017; Jafer \& Hassan, 2019), and membrane separation (Zoubeik et al., 2017; Zsirai et al., 2018). Several efforts have been made to explore the strong oxidation performance of the Fenton process. The photovoltaic cell Electro-Fenton process is an emerging Fenton process and has attracted considerable attention for removing organic substances from dye wastewater. Fenton oxidation process consists of the reaction between $\mathrm{H}_{2} \mathrm{O}_{2}$ and $\mathrm{Fe}^{2+}$ in acidic solution to produce hydroxyl radicals, a highly oxidant $\mathrm{OH}$ species responsible for pollutant degradation (Gutierrez-Mata et al., 2017). As it is technically simple, low-cost and non-toxic because $\mathrm{H}_{2} \mathrm{O}_{2}$ and iron are its main reactants; the Fenton's process is one of the most viable advanced oxidation processes (AOP). The traditional Fenton process uses homogeneous catalysts, and is confronted with problems like slower ferrous ion renewal rate and extreme iron clay manufacture. Nonetheless, these disadvantages 
have to be overcome if this method is to be adopted on a commercial scale. This was trapped by the heterogeneous electrochemical advanced oxidation processes (EAOPs) after the electric fenton procedure (Baiju et al., 2018). EAOP has unique electro-oxidation advantages aimed at the comprehensive oxidation of tenacious organic content in wastewater (Divyapriya et al., 2018). The electro-Fenton eco-friendly methods has some exciting features, for instance high adaptability, excellent efficiency, high acquiescence and ecological compatibility, which distinguishes them from other AOPs (Ganiyu et al., 2018; X. Li et al., 2017). In a Photovoltaic cell Electro-Fenton process, pollutants are detached by Fenton's reagents composed of anodic oxidation on the anode surface. Ordinarily, anodic oxidation is not suitable for mineralization of most aromatic contaminants due to the formation of strong carboxylic acids (He \& Zhou, 2017). These biodegradable techniques possess some exciting features, for example, high flexibility, excellent competence, long acquiescence, and ecological compatibility (Forat Y. AlJaberi et al., 2020). This process variance includes the in-situ generation of highly reactive oxidizing reagents, which are free radicals obtained from the reaction between $\mathrm{H}_{2} \mathrm{O}_{2}$ and $\mathrm{Fe}^{2+}$ (Buftia et al., 2018), (Atiyah et al., 2020). The crucial limits of the process are narrow $\mathrm{pH}$ range (2.0-3.0) and iron residue in the treated wastewater. The significant drawbacks of chemical treatment techniques are low removal efficiency and long separation time. The chemical methods also require a large amount of oxidant, low $\mathrm{pH}$, and conductivity adjustment, making the process not cost-effective. Electrochemical methods have received immense attention recently because of the smooth process and small amount of chemicals required (Davarnejad et al., 2014; Brillas et al., 2003).

The objectives of this study are to investigate the organic content removal of methyl orange wastewater by using photovoltaic cell ElectroFenton Oxidation and to find the optimum concentration of $\mathrm{H}_{2} \mathrm{O}_{2}$, current and electrolysis time for best removal efficiency.

\section{Materials and methods}

\section{Materials}

All the reagents used in this investigation are of an analytical grade and distilled water was used to prepare the synthetic dye solution. The stock solution of $20 \mathrm{mg} / \mathrm{L}$ of organic concentre was prepared from methyl orange (MO) using double distilled water. Figure 1 gives the chemical structure of $\mathrm{MO} . \mathrm{NaOH}$ (98\% purity) and $\mathrm{HCl}$ (37\% purity) were purchased from India.

\section{Electrodes and photovoltaic cell}

The electrodes used in this study are aluminium and iron as anode and cathode, respectively. The dimension of the iron electrode is $10 \mathrm{~cm} \mathrm{x}$ $4 \mathrm{~cm} \times 0.3 \mathrm{~cm}$, that of the Aluminum electrode is $10 \mathrm{~cm} \times 4 \mathrm{~cm} \times 0.15 \mathrm{~cm}$. The active area of the electrodes was maintained as $30 \mathrm{~cm}^{2}$, and the inner electrode spacing was maintained as $6 \mathrm{~cm}$. The electrochemical cell (Figure 2a) is composed of four blocks of acrylic, and sheets of

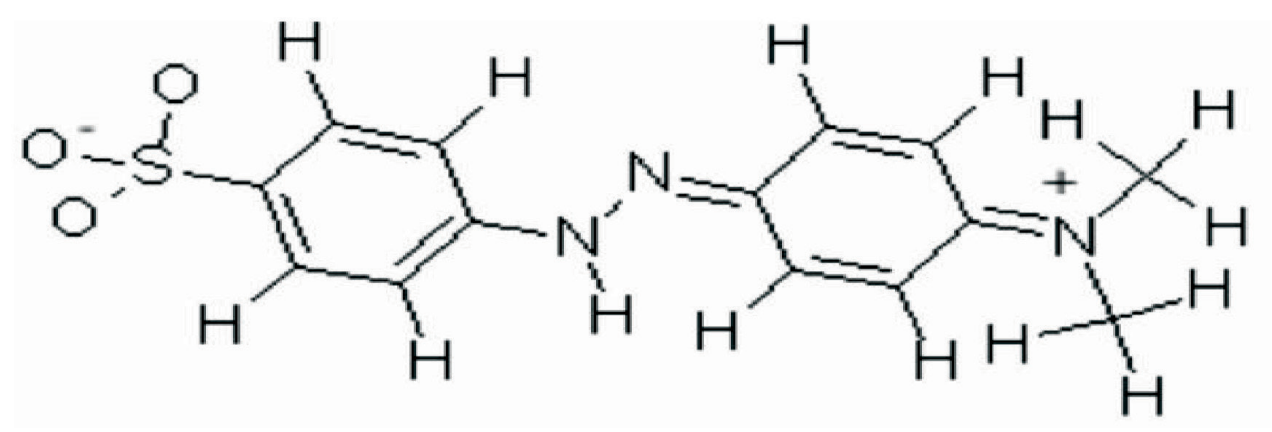

Figure 1: Description of the structure of methyl orange 
silicone gaskets placed between them to prevent leaks. This cell shape permits two possible anode locations, at the anolyte section at the end of the plate (between the blocks of acrylic, the distance between anode and cathode was $1 \mathrm{~cm}$ ) is presented in Figure $2 b$.

\section{Analytical Measurements}

Methyl orange concentrate in aqueous solution was determined at maximum absorption wavelength $(464.5 \mathrm{~nm})$ using a UV-spectra meter (UV-1800 Shimadzu, Japan) spectrophotometer connected to a PC. Turbid meter (Lovibond, SN 10/1471, and Germany) and $\mathrm{pH}$ capacities were made through a pH meter (Model 2906, Jenway $\left.\mathrm{L}_{\mathrm{td}}, \mathrm{UK}\right)$, correspondingly.

\section{Experimental Procedure}

In the Photovoltaic cell Electro-Fenton procedure, the experiment was performed in a batch reactor containing an $800 \mathrm{~mL}$ glass reactor with $300 \mathrm{~mL}$ of methyl orange. The solution was prepared by diluting the stock with distilled water, and the initial $\mathrm{pH}$ was tuned to 3 by $1 \mathrm{~N}$ sulfuric acid and sodium hydroxide. The electrodes were connected to a DC power source (RXN-305D) from the photovoltaic cell (solar energy) and supplementary $0.2 \mathrm{gm}$ of $\mathrm{NaCl}$. DC voltage was conserved as $29.6 \mathrm{~V}$. The reactor was operated for 10 minutes to sweep the $\mathrm{Fe}^{2+}$ ions, and subsequently, $\mathrm{H}_{2} \mathrm{O}_{2}$ was added with continuous stirring (Figure 3 ). The samples were allowed to rest at a regular time and centrifuged at $2000 \mathrm{rpm}$ (to separate the sludge) for 10 min, and the supernatant was allowed to settle to estimate the amount of organics left in the

a
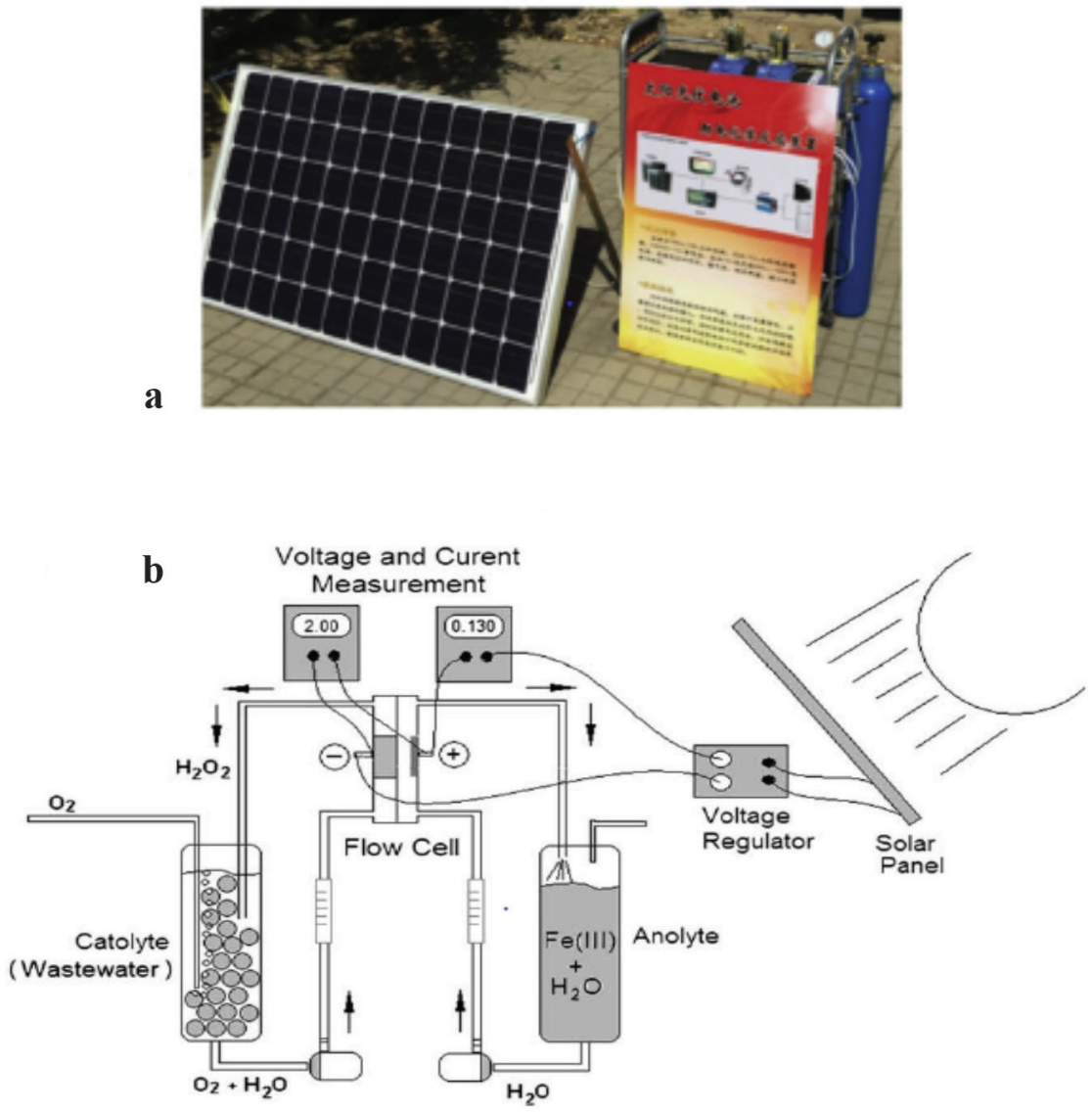

Figure 2: a) Main parts of the flow-cell. b) Hydraulic circuit, flow-cell, and solar panel 
solution. Methyl orange wastewater reduction was expressed as the ratio of remaining organic matter at time $t\left(C_{t}\right)$ to the initial concentration of the organic matter $\left(\mathrm{C}_{0}\right)$. Furthermore, the effect of $\mathrm{H}_{2} \mathrm{O}_{2}$ amount, current and time were studied. Before the commencement of the photovoltaic cell Electro-Fenton procedure, all the electrodes were cleaned with water to prevent further reaction. The electrodes were previously saturated in $1 \mathrm{~N}$ hydrochloric acid for 1 hour, and subsequently in $1 \mathrm{M}$ sodium hydroxide for 1 hour. The electrodes were put in distilled water when not in use. After each use, the electrodes were eroded in $1 \mathrm{~N} \mathrm{HCl}$ and $1 \mathrm{M}$ $\mathrm{NaOH}$ to eliminate any likely contamination. The initial conductivity of the solution was 126 $\mathrm{ms} / \mathrm{cm}$. The significant bounds of the process is the narrow working $\mathrm{pH}(2.0-3.0)$ and iron residue in the conserved water (Davarnejad et al, 2014).

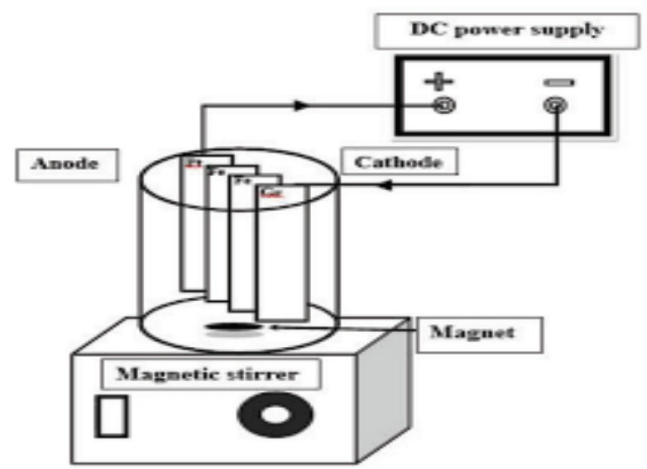

Figure 3: Schematic of the electrooxidation reactor

Energy consumption $\left(\mathrm{kWh} / \mathrm{m}^{3}\right)$ is a significant aspect of such treatment approaches. Consequently, it can be envisioned using the following equation (Forat Yasir AlJaberi, 2018):

$$
\mathrm{E}=(\mathrm{U} . \mathrm{I} . \mathrm{t}) /(1000 . \mathrm{V})
$$

Where $U$ is the applied voltage $(V), I$ is the current (A), $\mathrm{t}$ is the electrolysis time (h), and $\mathrm{V}$ is the volume of the methyl orange $\left(\mathrm{m}^{3}\right)$.

The variation of organic content in methyl orange concentrate through the electroFenton procedure was measured using a UV spectrophotometer (UV-1800 Shimadzu, Japan) at $464.5 \mathrm{~nm}$. The organic removal efficiency was determined using the following Equation (2):

$$
\eta=\frac{C_{.}-C_{t}}{C_{.}} x 100
$$

Where $\eta$, percentage of organic matter removed (removal efficiency); Co, measured concentration before treatment $(\mathrm{mg} / \mathrm{L}) ; \mathrm{Ct}$ concentration value after treatment $(\mathrm{mg} / \mathrm{L})$.

\section{Statistical Model}

A statistical technique, response surface methodology (RSM) as well as the statistical program Minitab-17, were used to design the experiments and predict the influence of the operational factors individually and in interaction with each other. The main impacts of these factors: electrolysis time $\left(X_{1}\right), \operatorname{rpm}\left(X_{2}\right)$, Current $\left(\mathrm{X}_{3}\right)$ and $\mathrm{H}_{2} \mathrm{O}_{2}$ concentration $\left(\mathrm{X}_{4}\right)$ were studied according to their ranges shown in Table 1. The natural and coded values of the operational variables are listed in Table 2. These variables were chosen on the basis of preliminary experiments before starting the research methodology. The time chosen was because the electrochemical processes occur at a high speed. Similar situation with respect to the rest of the variables.

Table 1: Operational parameters

\begin{tabular}{lc}
\hline \multicolumn{1}{c}{ Parameters } & Ranges \\
\hline $\mathrm{X}_{1}:$ electrolysis time $(\mathrm{min})$ & $5-15$ \\
$\mathrm{X}_{2}:$ rpm & $100-200$ \\
$\mathrm{X}_{3}:$ Current (A) & $05-2$ \\
$\mathrm{X}_{4}: \mathrm{H}_{2} \mathrm{O}_{2}$ concentration $(\mathrm{ppm})$ & $25-100$ \\
\hline
\end{tabular}

\section{Results and discussion}

\section{The Effect of Current}

Figure 4 presents the significance of current on the performance of the Photovoltaic cell Electro-Fenton system. The experiments were performed by varying the current from 0.5 to 2 Amps. The MO removal efficiency increases with increasing current, and the maximum removal efficiency of $98.46 \%$ was achieved at $1.69 \mathrm{~mA}, 200 \mathrm{rpm}$ for 15 minutes using 87.87 ppm $\mathrm{H}_{2} \mathrm{O}_{2}$, and the solution $\mathrm{pH}$ of 3. A higher current would lead to higher production rate of $\mathrm{H}_{2} \mathrm{O}_{2}$ on the surface of the cathode. As a 
result, free radicals will accumulate in the bulk solution, leading to a greater degradation of the oil in the wastewater. Similar consequences have been observed in the electro-Fenton treatment of ibuprofen (Liu et al., 2018). The removal efficiency obtained at $0.5 \mathrm{~mA}$ is $91 \%$ in the heterogeneous electrooxidation process at the same condition. As the applied current to the electrode increases, the rate of activity of $\mathrm{H}_{2} \mathrm{O}_{2}$ is amplified proportionately, thereby increasing the rate of generation of $\mathrm{HO}^{*}$ radical to enhance the removal efficiency at $1.69 \mathrm{~mA}$ at $0.5 \mathrm{~V}$ and $1.0 \mathrm{~V}$. Increasing current to $2 \mathrm{~mA}$, reduces the recovery efficiency to $86 \%$ due to the occurrence of subsequent ide reactions: (i) growth of hydrogen at cathode (Equation (8)), (ii) oxidation of $\mathrm{H}_{2} \mathrm{O}_{2}$ at anode (Equation (4))

$$
\begin{aligned}
& 2 \mathrm{H}_{2} \mathrm{O}_{2}+2 e^{-} \rightarrow \mathrm{H}_{2}+\mathrm{HO}^{-} \\
& \mathrm{H}_{2} \mathrm{O}_{2} \rightarrow \mathrm{O}_{2}+2 \mathrm{H}^{+}+2 e^{-}
\end{aligned}
$$

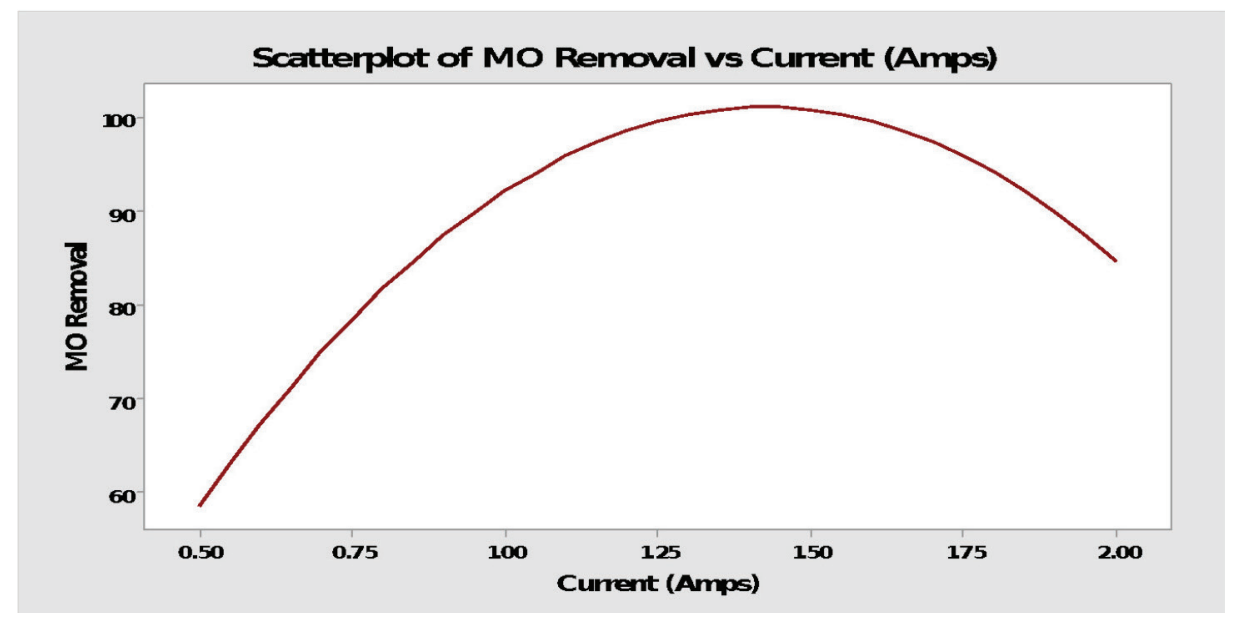

Figure 4: The effect of current on the recovery efficiencies of MO wastewater

\section{The of Hydrogen Peroxide}

In the direction of the best illustration, the role of $\mathrm{H} 2 \mathrm{O} 2$ concentration on a photovoltaic fog Electro-Fenton of methyl orange wastewater in this study was occupied in electrical oxidation. Hydrogen peroxide, as a dominant source of $\mathrm{OH} \bullet$, is always considered as a critical parameter in the Fenton and Fenton-like processes. But, an excessive $\mathrm{H}_{2} \mathrm{O}_{2}$ dosage can scavenge hydroxyl radicals and reduce efficiency of the process; hence raising the cost of treatment (Jaafarzadeh et al., 2018). The concentration of $\mathrm{H}_{2} \mathrm{O}_{2}$ was varied during the electro-Fenton treatment within electrolysis time from 5 to 15 min). Figure 5 presents the removal efficiency represented by percentage MO removal when $\mathrm{H}_{2} \mathrm{O}_{2}$ concentration is increased from 25 to $87.87 \mathrm{mg} / \mathrm{L}$. This is attributed to the generation of more $\mathrm{OH}$ radicals. The removal efficiency is increased gradually with increasing $\mathrm{H}_{2} \mathrm{O}_{2}$ concentration until it reaches the best value, then the value decreases, where the free root starts to react with hydrogen peroxide. Nevertheless, a further increase in the level of $\mathrm{H}_{2} \mathrm{O}_{2}$ declines the removal efficiency because the reaction rate plateaus. This trend could be attributed to the recombination of $\mathrm{OH}$ radicals in addition to the decay of $\mathrm{H}_{2} \mathrm{O}_{2}$ into water and oxygen. Thus, excess $\mathrm{H}_{2} \mathrm{O}_{2}$ may lead to the ingestion of active oxidized free radicals, which leads to further termination of the organolysis reaction. Because of that, a balance is reached between low levels of $\mathrm{H}_{2} \mathrm{O}_{2}$ and extra quantities of it. These observations are similar to the one reported by Haider et al. ( 2018). 


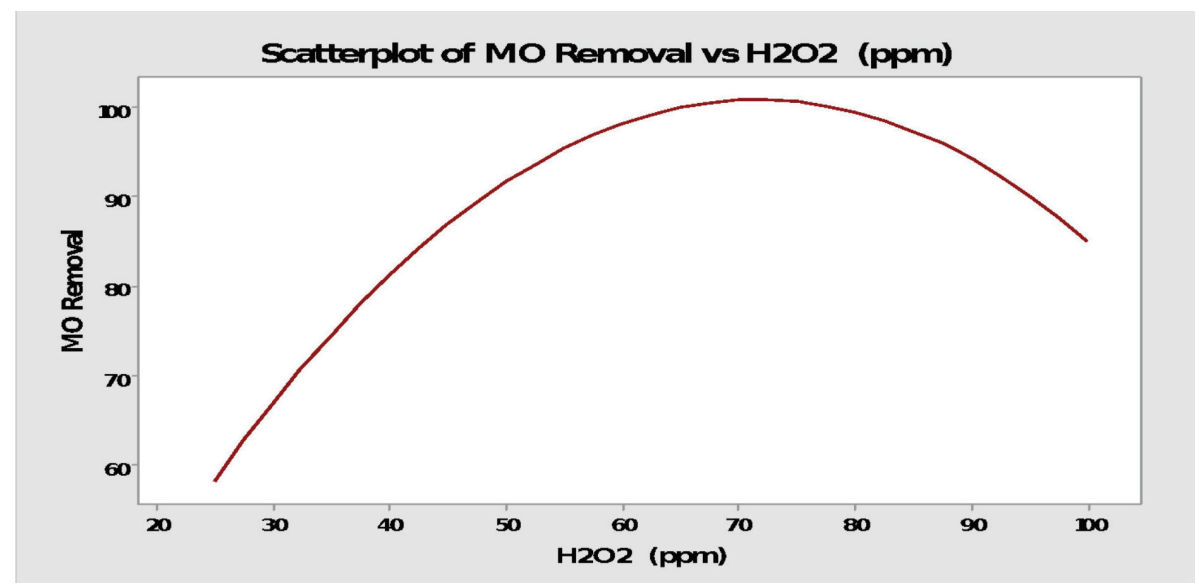

Figure 5: The $\mathrm{H}_{2} \mathrm{O}_{2}$ effect on the recovery efficiencies of $\mathrm{MO}$ wastewater

\section{The Effect of Agitation Speed}

Electro-Fenton oxidation of organic content in $\mathrm{MO}$ wastewater was undertaken employing varying degrees of agitation. It was observed that the MO removal increased linearly, with faster stirring speed. The maximum removal efficiency attained is $94.3 \%$ using $170 \mathrm{rpm}$ for 15 min with 87.87 ppm $\mathrm{H}_{2} \mathrm{O}_{2}$ (Figure 6). Reduced organic eliminations were observed at speeds $\leq 100 \mathrm{rpm}$. This trend is mainly because an increase in the agitation speed increases the mass transfer (Sundarapandiyan et al., 2009). Treatment of synthetic waste and wastewater from the dye and tanning industry was deliberate, and it was decided that stirring was one of the major factors in the electrochemical process (Szpyrkowicz, 2006). Therefore, the development in oxidation might be credited to higher mass transfer through agitation.

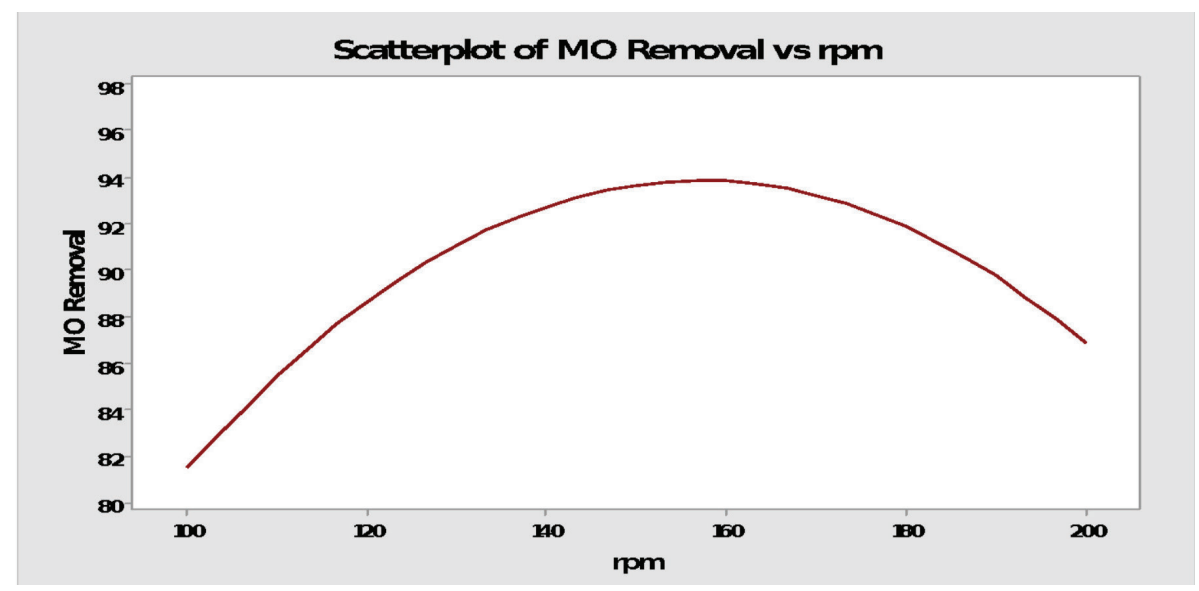

Figure 6: The rpm effect on the removal efficiencies of MO wastewater 


\section{The Effect of Electrolysis Time}

The effect of electrolysis time was studied in a wastewater solution, which contains 20 ppm organic content $(\mathrm{MO})$ at a $\mathrm{pH}$ of 3 . The highest removal efficiency was achieved using $175 \mathrm{rpm}$ ppm and $1.69 \mathrm{Am}$ for $15 \mathrm{~min}$. The removal efficiency of organic in methyl orange increased with longer electrolysis time (Fig .7). This result is in agreement with that of Gaber et al. (2012). This trend is because of an increase in the activity of the adsorption process, which occurred throughout the electroFenton reactor with increasing electrolysis time (Apaydin, 2014). Increasing the oxidation time leads to a step-by-step detoxification until the formation of mineral tin and $\mathrm{CO}_{2}$ (Yong et al., 2017). Therefore, complete mineralization was obtained.

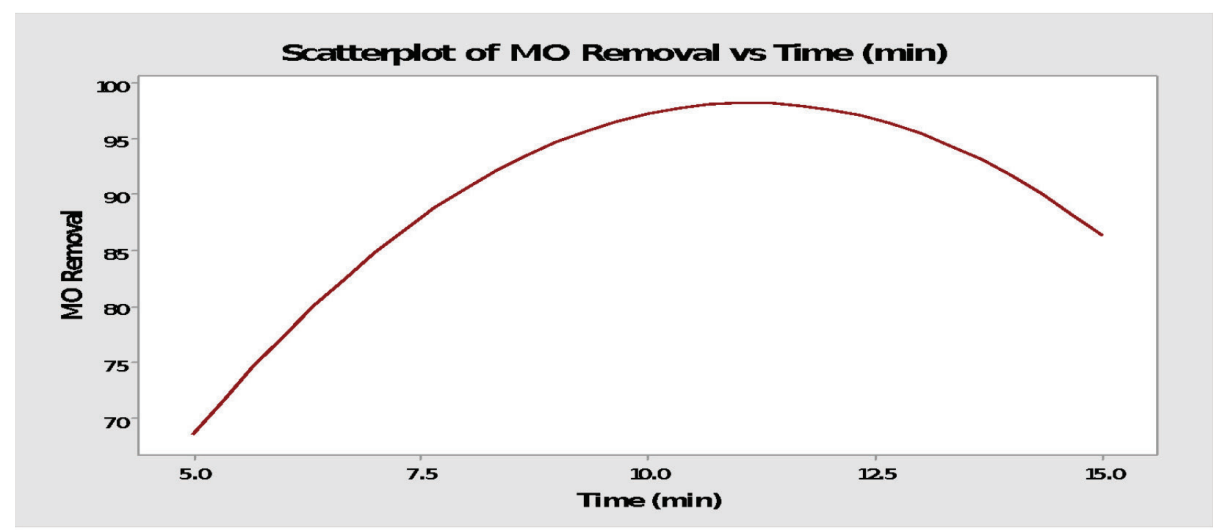

Figure 7: The electrolysis time effect on the removal efficiencies of MO wastewater

\section{Optimization of Operational Variables}

The best values of electrolysis time, rpm, and current and hydrogen peroxide were obtained using a statistical software program
(Minitab-17). Figure 8 presents the results of the D-optimization study. The best value of the removal efficiency of the organic content is $98.46 \%$.

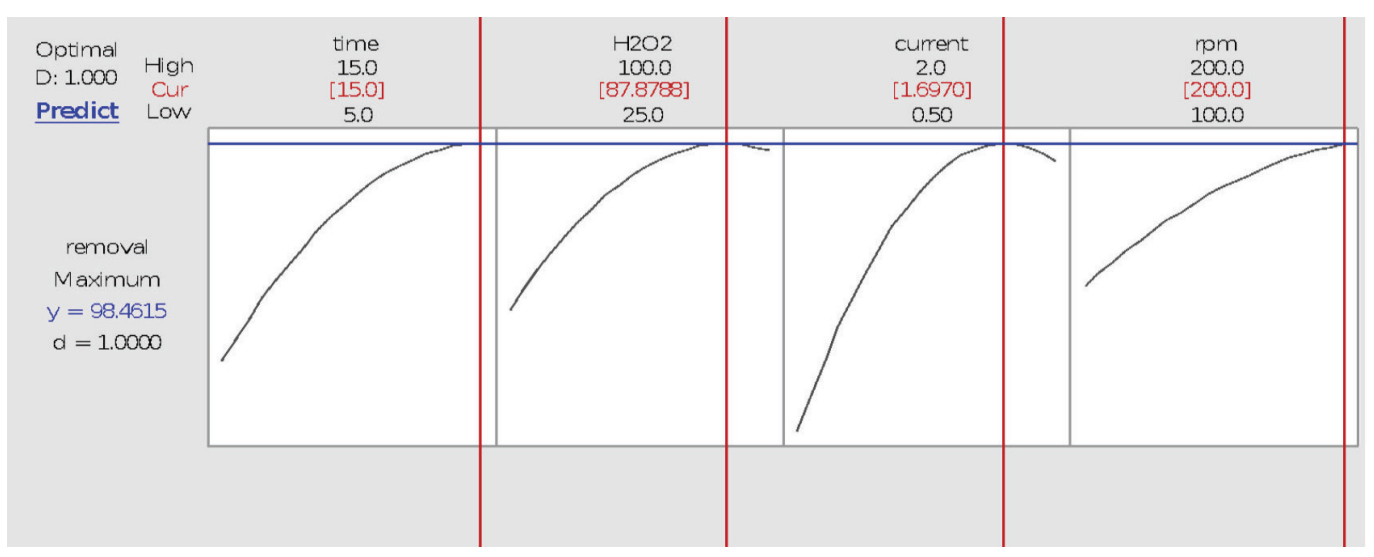

Figure 8: The optimum values of the operational variables and the validated values of the studied responses for the treatment of MO wastewater 


\section{Estimation of Energy Consumption}

The acceptance of electro-Fenton technology in wastewater treatment is influenced by anode material, energy consumption and operating cost. Figure 9 presents the energy consumption, as a function of current and electrolysis time, during Photovoltaic cell Electro-Fenton removal of organic in methyl orange wastewater. It is observed, for all types of wastewater, that the values are relative to the applied time throughout Photovoltaic cell Electro-Fenton treatment (da Silva et al., 2013).

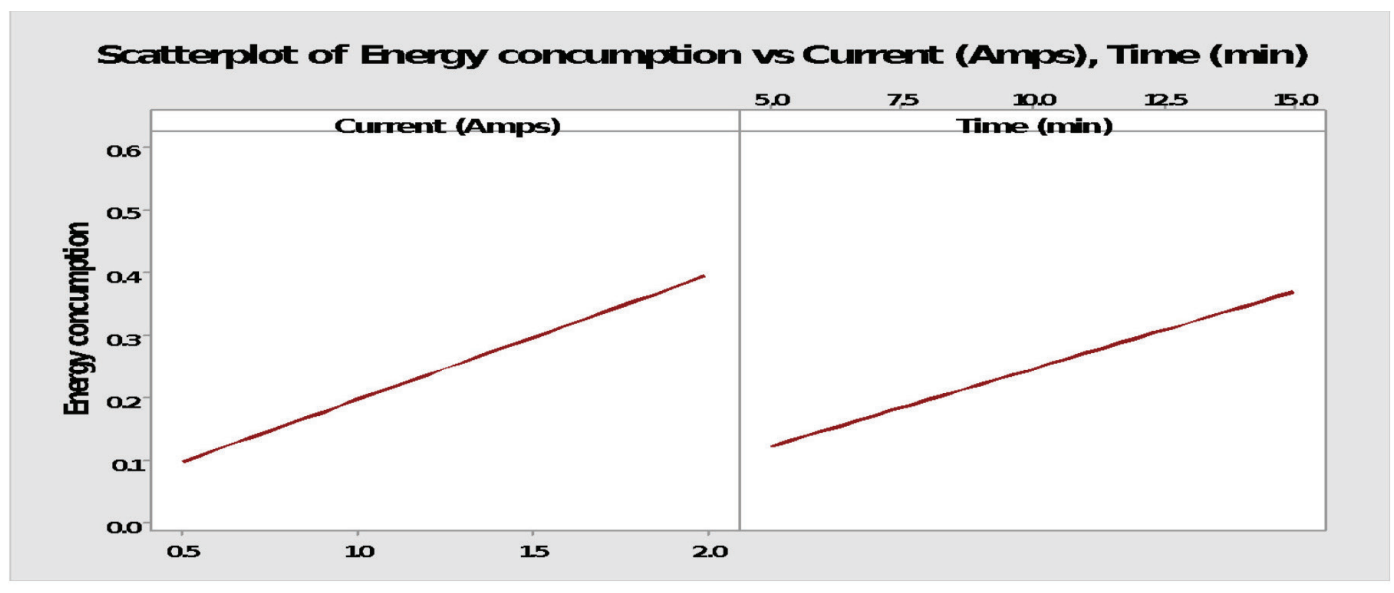

Figure 9: The effect of the operational variables on the energy consumption for the treatment of $20 \mathrm{mg} / \mathrm{L}$ methyl orange wastewater

Based on the optimum values of current and electrolysis time that was determined, the energy consumption is $39.4 \mathrm{kWh} / \mathrm{m}^{3}$. Energy consumption is a function of the active variables during the electrooxidation to remove the organic substances. The increase in energy consumption is due to increased current and the electrolysis time. However, the current is more crucial for the determination of energy consumption, which agrees with the literature (Ganiyu et al., 2018).

\section{Regression Models}

The relationship between the responses and the independent variables is obtained using the second-order model by a least-squares method as follows (Davarnejad et al., 2014):

$\mathrm{Y}=\mathrm{B}_{0}+\sum_{\mathrm{i}=1}^{\mathrm{q}} \mathrm{B}_{\mathrm{i}} \mathrm{X}_{\mathrm{i}}+\sum_{\mathrm{i}=1}^{\mathrm{q}} \mathrm{B}_{\mathrm{ii}} \mathrm{X}_{\mathrm{i}}^{2}+\sum_{\mathrm{i}} \sum_{\mathrm{j}} \mathrm{B}_{\mathrm{ij}} \mathrm{X}_{\mathrm{i}} \mathrm{X}_{\mathrm{j}}+\varepsilon$

Where $\mathrm{Y}$ is the investigated response; $\mathrm{X}_{1}$, $\mathrm{X}_{2}$, to $\mathrm{Xq}$ are the working variables; $\mathrm{B}_{\mathrm{o}}$ is the regression constant. $\mathrm{B}_{\mathrm{i}}$ is the linear regression constant, $\mathrm{B}_{\mathrm{ii}}$ is the squared regression constant, and $\mathrm{B}_{\mathrm{ij}}$ is the relationship regression constant; $\varepsilon$ is a random error. Table 3 presents the values of the operational variables, percentage elimination (MO removal efficiency), and energy consumption.

\section{Conclusion}

This paper investigates the possibility of using Photovoltaic cell electro-Fenton oxidation technology for the removal of organic content from methyl orange wastewater by directly connecting the electro-Fenton reactor to the photovoltaic generator. In this work, the ElectroFenton technique is shown to be promising for the treatment of organic substances from wastewater. The operating parameters were changed to achieve the highest removal efficiency. The mathematical relationship obtained has a reasonably high regression constant for all the responses, showing the satisfactory adjustment of the second-order polynomial model. The maximum organic removal of $98 \%$ was achieved at a $\mathrm{pH}$ of 3 , electrolysis time of 15 minutes, applied current 
of $1.69 \mathrm{~mA}$, and $87.87 \mathrm{ppm}$ of $\mathrm{H}_{2} \mathrm{O}_{2}$. It appears that Nano-porosity is essential to facilitate the decay of $\mathrm{H}_{2} \mathrm{O}_{2}$, which eventually favors the formation of hydroxyl radicals. Because of the good performance of Photovoltaic cell ElectroFenton operation, this technique is promising for treatment of simulated wastewater.

\section{Acknowledgments}

The authors thank for Al-Qasim Green University, college of water resources engineering, Babylon and Ministry of Higher Education Iraq for support this research.

\section{References}

Ali A. Hassan, Haider T. Naeem, \& Raid T. Hadi. (2018). Degradation of oily waste water in aqueous phase using solar (ZnO, TiO2 and A12O3) catalysts. Pak. J. Biotechnol, 909-916.

Ali A. Hassan, \& Khalid M. Mousa Alzobai. (2019). Chemical oxidation for oil separation from oilfield produced water under UV irradiation using Titanium Dioxide as a nano-photocatalyst by batch and continuous techniques. International Journal of Chemical Engineering.

Ali Saleh Jafer, Ali A. Hassan, \& Zahraa Tawfiq Naeem. (2019). A study on the potential of moringa seeds in adsorption of organic content from water collected from oilfield refinery. Pak. J. Biotechnol.

AlJaberi, F. Y. (2018). Investigation of electrocoagulation reactor design effect on the value of total dissolved solids via the treatment of simulated wastewater. Desalination and Water Treatment, 120, 141-149.

AlJaberi, F. Y., Abdulmajeed, B. A., Hassan, A. A., \& Ghadban, M. L. (2020). Assessment of an electrocoagulation reactor for the removal of oil content and turbidity from real oily wastewater using response surface method. Recent Innovations in Chemical
Engineering (Formerly Recent Patents on Chemical Engineering), 13(1), 55-71.

Alvarez-Corena, J. R., Bergendahl, J. A., \& Hart, F. L. (2016). Advanced oxidation of five contaminants in water by UV/ TiO2: Reaction kinetics and byproducts identification. Journal of Environmental Management, 181, 544-551.

Apaydin, Ö. (2014). Reduction of cod in wastewater from a textile industry by electro-fenton process. Global Nest Journal, 16(3), 536-542.

Atiyah, A. S., Al-Samawi, A. A. A., \& Hassan, A. A. (2020). Photovoltaic cell electro-fenton oxidation for treatment oily wastewater. AIP Conference Proceedings, 2235, 20009.

Baiju, A., Gandhimathi, R., Ramesh, S. T., \& Nidheesh, P. V. (2018). Combined heterogeneous Electro-Fenton and biological process for the treatment of stabilized landfill leachate. Journal of Environmental Management, 210, 328-337.

Brillas, E., Boye, B., \& Dieng, M. M. (2003). Peroxi-coagulation and photoperoxicoagulation treatments of the herbicide 4-chlorophenoxyacetic acid in aqueous medium using an oxygen-diffusion cathode. Journal of the Electrochemical Society, 150(3), E148-E154.

Buftia, G., Rosales, E., Pazos, M., Lazar, G., \& Sanromán, M. A. (2018). Electro-fenton process for implementation of acid black liquor waste treatment. Science of the Total Environment, 635, 397-404.

da Silva, A. J. C., dos Santos, E. V., de Oliveira Morais, C. C., Martínez-Huitle, C. A., \& Castro, S. S. L. (2013). Electrochemical treatment of fresh, brine and saline produced water generated by petrochemical industry using $\mathrm{Ti} / \mathrm{IrO} 2-\mathrm{Ta} 2 \mathrm{O} 5$ and $\mathrm{BDD}$ in flow reactor. Chemical Engineering Journal, 233, 47-55.

Davarnejad, R., Mohammadi, M., \& Ismail, A. F. (2014). Petrochemical wastewater treatment by electro-fenton process using 
aluminum and iron electrodes: Statistical comparison. Journal of Water Process Engineering, 3, 18-25.

Divyapriya, G., Nambi, I., \& Senthilnathan, J. (2018). Ferrocene functionalized graphene based electrode for the electro- fenton oxidation of ciprofloxacin. Chemosphere, 209, 113-123.

El-Din, G. A., Amer, A. A., Malsh, G., \& Hussein, M. (2017). Study on the use of banana peels for oil spill removal. Alexandria Engineering Journal.

Fathy, M., El-Sayed, M., Ramzi, M., \& Abdelraheem, O. H. (2017). Adsorption separation of condensate oil from produced water using ACTF prepared of oil palm leaves by batch and fixed bed techniques. Egyptian Journal of Petroleum.

Gaber, M., Abu Ghalwa, N., Khedr, A. M., \& Salem, M. F. (2012). Electrochemical degradation of reactive yellow 160 dye in real wastewater using $\mathrm{C} / \mathrm{PbO} 2-, \mathrm{Pb}$. Journal of Chemistry, 2013.

Galvão, S. A. O., Mota, A. L., Silva, D. N., Moraes, J. E. F., Nascimento, C. A., \& Chiavone-Filho, O. (2006). Application of the photo-fenton process to the treatment of wastewaters contaminated with diesel. Science of the Total Environment, 367(1), 42-49.

Ganiyu, S. O., Zhou, M., \& Martínez-Huitle, C. A. (2018). Heterogeneous electro-fenton and photoelectro-fenton processes: A critical review of fundamental principles and application for water/wastewater treatment. Applied Catalysis B: Environmental.

Gutierrez-Mata, A. G., Velazquez-Martínez, S., Álvarez-Gallegos, A., Ahmadi, M., Hernández-Pérez, J. A., Ghanbari, F., \& Silva-Martínez, S. (2017). Recent overview of solar photocatalysis and solar photofenton processes for wastewater treatment. International Journal of Photoenergy, 2017.
Haider T. Naeem, \& Ali A. Hassan. (2018). Effectiveness \& economy of sawdust wood adsorbents in removing anionic dyes of aqueous solutions. Pak. J. Biotechnol, 311320 .

Haider T. Naeem, Ali A. Hassan, \& Raid T. Al-khateeb. (2018). Wastewater-(Direct Red Dye) Treatment-Using Solar Fenton Process. Pharm. Sci. \& Res, 10(9), 23092313.

Hassan, A. A., \& Haider T. Naeem. (2019). A comparative study of chemical material additives on polyacrylamide to treatment of waste water in refineries. IOP Conf. Series: Materials Science and Engineering.

He, H., \& Zhou, Z. (2017). Electro-fenton process for water and wastewater treatment. Critical Reviews in Environmental Science and Technology, 47(21), 2100-2131.

Jaafarzadeh, N., Takdastan, A., Jorfi, S., Ghanbari, F., Ahmadi, M., \& Barzegar, G. (2018). The performance study on ultrasonic/Fe3O4/H2O2 for degradation of azo dye and real textile wastewater treatment. Journal of Molecular Liquids, 256, 462-470.

Jafer, A. S., \& Hassan, A. A. (2019). Removal of oil content in oilfield produced water using chemically modified kiwi peels as efficient low-cost adsorbent. Journal of Physics: Conference Series, 1294, 72013.

Li, Q., Kang, C., \& Zhang, C. (2005). Waste water produced from an oilfield and continuous treatment with an oil-degrading bacterium. Process Biochemistry, 40(2), 873-877.

Li, X., Jin, X., Zhao, N., Angelidaki, I., \& Zhang, Y. (2017). Novel bio-electro-fenton technology for azo dye wastewater treatment using microbial reverse-electrodialysis electrolysis cell. Bioresource Technology, 228, 322-329.

Liu, D., Zhang, H., Wei, Y., Liu, B., Lin, Y., Li, G., \& Zhang, F. (2018). Enhanced degradation of ibuprofen by heterogeneous 
electro-Fenton at circumneutral $\mathrm{pH}$. Chemosphere, 209, 998-1006.

Sundarapandiyan, S., Sivakumar, V., Rajeswari, G., \& Saravanan, P. (2009). Effect of sonication on electro-oxidation of organic pollutants in saline wastewater. Water Environment Research, 81(3), 319-324.

Szpyrkowicz, L. (2006). Application of electrochemical oxidation for treatment of industrial wastewater-The influence of reactor hydrodynamics on direct and mediated processes. Journal of Chemical Technology \& Biotechnology: International Research in Process, Environmental \& Clean Technology, 81(8), 1375-1383.

Yong, X.-Y., Gu, D.-Y., Wu, Y.-D., Yan, Z.-Y., Zhou, J., Wu, X.-Y., Wei, P., Jia, H.-H.,
Zheng, T., \& Yong, Y.-C. (2017). BioElectron-Fenton (BEF) process driven by microbial fuel cells for triphenyltin chloride (TPTC) degradation. Journal of Hazardous Materials, 324, 178-183.

Zoubeik, M., Ismail, M., Salama, A., \& Henni, A. (2017). New developments in membrane technologies used in the treatment of produced water: A review. Arabian Journal for Science and Engineering, 1-26.

Zsirai, T., Qiblawey, H., Buzatu, P., Al-Marri, M., \& Judd, S. J. (2018). Cleaning of ceramic membranes for produced water filtration. Journal of Petroleum Science and Engineering, 166, 283-289. 